\title{
Analisis Penilaian Kesehatan Keuangan Lembaga Penjamin Dengan Menggunakan Surat Edaran OJK Nomor 18/SEOJK.05/2018
}

Financial health assessment analysis of guarantee institutions using OJK circular letter number 18/SEOJK.05/2018

\section{Anggraeni Novitasari}

Program Studi D4 Keuangan Syariah, Politeknik Negeri Bandung

E-mail: anggraeni.novitasari.ksy16@polban.ac.id

\section{Kristianingsih}

Jurusan Akuntansi, Politeknik Negeri Bandung

E-mail: mep2008_kries@yahoo.com

\section{Hasbi Assidiki Mauluddi}

Jurusan Akuntansi, Politeknik Negeri Bandung

E-mail: hasbi.assidiki@polban.ac.id

\begin{abstract}
This study aims to analyze the financial health of the Sharia Guarantee Institution for the period 2014 to 2018 using liquidity ratio analysis, Gearing Ratio, and Profitability using analysis techniques of the Health Level of the Guarantee Company Financial Institution based on the Regulation of the Financial Services Authority (SAL SEOJK) Number 18 /SEOJK.05/2018. This research is a descriptive research type, which describes the financial performance of PT Asuransi Jamkrindo Syariah and PT Penjaminan Jamkrindo Syariah. The data research method used in this research is the documentation method. The type of data used in the research is secondary data, which is obtained from the annual financial reports of PT Asuransi Jamkrindo Syariah and PT Penjaminan Jamkrindo Syariah for the period 2014 to 2018. The results obtained in this study are the level of health at PT Asuransi Askrindo Syariab and PT Penjaminan Jamkrindo. This Sharia falls into a fairly healthy category for five years. Whereas for 2014, PT Penjaminan Jamkrindo Syariah received an unhealthy category level. This is supported by the results of research on 1) the gearing ratio of the two companies that received a very poor category for five years period 2) the performance in the liquidity ratio shows that PT Penjaminan Jamkrindo Syariah received a very poor category in the first two years of the period while PT Asuransi Asuransi Askerindo Syariah received very good category value in five years period 3) the profitability ratio of the two companies, PT Penjaminan Jamkrindo Syariah got a pretty good category in 2014 and got a very good category in the following year period, PT Asuransi Askrindo Syariah got a good category score in 2017 while the other period of the year gets very good category.
\end{abstract}

Keywords: guarantees, financial ratios, liquidity, gearing ratio, profitability.

\section{Pendahuluan}

Lembaga Penjaminan merupakan salah satu unsur penting bagi keberadaan Usaha Mikro, Kecil dan Menengah (UMKM) serta Koperasi. Hal ini dikarenakan dua sektor tersebut menjadi sektor yang penting bagi perbaikan perekonomian nasional. Apalagi saat ini Indonesia sedang 
bergerak aktif untuk memajukan perekonomian negara (Apriyanthi et al., 2020). Hal ini dapat dibuktikan dengan data menurut Kementrian Koordinator Bidang Perekonomian pada tahun 2018, UMKM terhadap PDB tumbuh hingga 60,34 persen dan secara jumlah, usaha kecil Menyumbang PDB lebih banyak yaitu mencapai 93,4 persen. Selain itu, dari sektor produktif UMKM, perkembangan ini dapat mempekerjakan lebih dari 107.6 juta penduduk Indonesia dan berkontribusi 60,6 persen terhadap PDB Indonesia.

Tabel 1. 1 Data Perkembangan UMKM di Indonesia

\begin{tabular}{|c|c|c|}
\hline No. & Tahun & $\begin{array}{c}\text { Total Jumlah Usaha (Kecil, } \\
\text { Mikro, dan Menengah) }\end{array}$ \\
\hline 1. & 2013 & 56.539 .560 \\
\hline 2. & 2014 & 57.900 .787 \\
\hline 3. & 2015 & 59.267 .759 \\
\hline 4. & 2016 & 61.656 .547 \\
\hline 5. & 2017 & 62.928 .077 \\
\hline 6. & 2018 & 63.000 .000 \\
\hline
\end{tabular}

Sumber: Situs depkop.go.id yang diolah

Meskipun UMKM memiliki peran penting dan memberikan kontribusi dalam perekonomian Indonesia, bisnis UMKM juga masih memiliki permasalahan seperti keterbatasan inovasi dan teknologi, serta yang paling banyak terjadi adalah karena keterbatasan akses pembiayaan yang disebabkan oleh persyaratan agunan yang masih diragukan oleh pihak perbankan (FEUI, 2011). Karena dengan berkembangnya jumlah pembiayaan diharapkan mampu mendorong kegiatan pada sektor tersebut dan meningkatkan sumbangan terhadap pembentukan GDP (I. Setiawan, 2020). Dengan hadirnya perusahaan penjaminan, hal ini dapat berdampak kepada penjembatanan antara terjamin UMKM yang belum mendapat akses ke perbankan karena berbagai faktor serta kepentingan terjamin dari sisi penggantian agunan dan kepentingan penerima jaminan (Perbankan/LKBB) untuk menyalurkan kredit atau pembiayaan.

Pada tahun 2008 Pemerintah menerbitkan Peraturan Presiden Nomor 2 tahun 2008 mengenai Lembaga Penjaminan yang diikuti dengan lahirnya Peraturan Menteri Keuangan Nomor 222/PMK.010/2008 tentang Perusahaan Penjaminan Kredit Dan Perusahaan Penjaminan Ulang Kredit yang kemudian diubah dengan Peraturan Menteri Keuangan Nomor 99/PMK.010/2000 tentang Perubahan atas Peraturan Menteri Keuangan Nomor 222/PMK.010/2008 tentang Perusahaan Penjaminan Kredit dan Perusahaan Penjaminan Ulang Kredit. Sejak diterbitkannya Peraturan Presiden dan Peraturan Menteri Keuangan tersebut, Lembaga Penjaminan Kredit Daerah (LPKD) mulai berdiri dan terus berkembang sampai saat ini.

Selain subjek dan objek penjaminan yang berkembang pesat, lahirnya UU Nomor 21 Tahun 2011 tentang Otoritas Jasa Keuangan (OJK) mengamanatkan peralihan kewenangan pengawasan terhadap lembaga penjaminan dari Menteri Keuangan kepada OJK dan pengaturan mengenai lembaga penjaminan mengacu pada Peraturan Otoritas Jasa Keuangan (POJK). Pada tahun 2017 OJK juga mengeluarkan peraturan Nomor 2/POJK.05/2017 tentang Penyelenggaraan Usaha Lembaga Penjamin (Lembaran Negara Republik Indonesia Tahun 2017 Nomor 7, Tambahan Lembaran Negara Republik Indonesia Nomor 6014). Sehubungan dengan amanat dari ketentuan pasal tersebut perlu diaturnya ketentuan 
pelaksanaan mengenai tata cara pengukuran kesehatan bagi lembaga penjamin dalam Surat Edaran Otoritas Jasa Keuangan Nomor 18/SEOJK.05/2018 mengenai kesehatan keuangan Lembaga Penjamin.

Dengan adanya peraturan yang mengatur tentang pengukuran kesehatan lembaga penjamin, masyarakat dapat mengetahui sejauh mana perusahaan Penjamin dapat menjamin pembiayaan yang telah dijaminkan oleh pihak perbankan. Hal ini dikarenakan sebagai perusahaan dengan bidang usaha penjamin kredit dari masyarakat, perusahaan penjaminan harus berada pada kondisi yang baik atau sangat baik, selain untuk membuktikan bahwa perusahaan tersebut layak untuk menjadi perusahaan penjaminan, juga untuk menjadi tumpuan perbankan dalam menjaminkan pembiayaannya kepada perusahaan penjaminan.

Saat ini Indonesia telah memiliki Perusahaan yang bergerak di bidang Penjaminan berstatus BUMN yaitu, PT Asuransi Kredit Indonesia (Persero) dan Perusahaan Umum Jaminan Kredit Indonesia (R. W. Setiawan, 2017). Kedua perusahaan ini juga telah memiliki anak Perusahaan yang bergerak di bidang Penjaminan Syariah dengan fokus untuk menjaminkan kegiatan usaha berbasis syariah yang kemudian disebut PT Jaminan Pembiayaan Askrindo Syariah Dan PT Penjaminan Jamkrindo Syariah.

Tabel 1. 2 Data Imbal Jasa Kafalah Perusahaan

\begin{tabular}{|c|c|c|c|}
\hline \multicolumn{4}{|c|}{ IMBAL JASA KAFALAH } \\
\hline Tahun & & $\begin{array}{l}\text { JAMKRINDO } \\
\text { Syariah }\end{array}$ & $\begin{array}{c}\text { PT ASKRINDO } \\
\text { Syariah }\end{array}$ \\
\hline 2014 & $\mathrm{Rp}$ & 9.694 .330 & Rp 47.407 .206 .739 \\
\hline 2015 & & 18.893.517.921 & Rp 111.148.991.593 \\
\hline 2016 & & 44.558.186.225 & Rp 156.215.848.198 \\
\hline 2017 & $\mathrm{Rp}$ & 68.832.364.309 & Rp 176.300.416.260 \\
\hline 2018 & $\mathrm{Rp}$ & 151.895 .237 .797 & Rp 223.484.500.864 \\
\hline
\end{tabular}

Sumber: Laporan Keuangan Perusahaan yang diolah

Salah satu faktor penting dalam rangka pengembangan usaha bisnis dan menampung risiko kerugian adalah modal (Halimatus \& Mauluddi, 2018). Menurut data yang diambil dari laporan keuangan kedua perusahaan penjamin syariah ini terlihat bahwa selama periode tahun yang ada sejak 2014 hingga tahun 2018 Imbal Jasa Kafalah atau fee atas penggunaan fasilitas penjaminan untuk penjaminan pembiayaan berdasarkan prinsip syariah (kafalah bil ujrah) menunjukkan peningkatan di setiap periodenya. Dengan semakin besar angka yang ditunjukkan maka semakin banyak pula pembiayaan yang dapat dijaminkan oleh perusahaan penjaminan. Namun walaupun jumlah dari Imbal Jasa Kafalah ini semakin besar nilainya, dalam menjalankan usaha penjaminan yang mengelola risiko usaha, diperlukan kapasitas penjaminan yang dapat memastikan kemampuan perusahaan dalam membayar kewajibannya. Kapasitas penjaminan sangat menentukan jumlah nilai penjaminan yang akan diakseptasi dan kemampuan melakukan kewajibannya. Lembaga Penjaminan tidak boleh melakukan penjaminan melebihi kapasitas penjaminannya karena dikhawatirkan akan mengalami kesulitan dalam penyelesaian klaim yang pada akhirnya akan merugikan penerima jaminan dan atau terjamin.

Dengan lahirnya Surat Edaran Otoritas Jasa Keuangan (SAL SEOJK No.18/SEOJK.05/2018) mengenai kesehatan keuangan Lembaga Penjamin dan fenomena yang terjadi pada peningkatan Imbal Jasa Kafalah dari dua perusahaan penjaminan, menjadi dasar penelitian dikarenakan belum adanya penelitian sejenis yang membahas secara analisis mengenai 
pengukuran kesehatan bagi lembaga penjamin menurut Surat Edaran Otoritas Jasa Keuangan Nomor 18/SEOJK.05/2018.

\section{Kajian Pustaka}

\subsection{Kinerja Keuangan}

Kinerja keuangan adalah suatu analisis yang dilakukan untuk melihat sejauh mana suatu perusahaan telah melaksanakan dengan menggunakan aturan-aturan pelaksanaan keuangan secara baik dan benar (Fahmi, 2012). Penilaian yang dilakukan atas kinerja keuangan akan didasarkan pada bagaimana cara perusahaan melaksanakan aturan-aturan keuangan yang ada secara efektif dan efesien (Setiawan dkk., 2020). Menurut Mardiasmo (2010) penilaian kinerja pada perusahaan sector public memiliki satu tujuan yang tidak lain adalah untuk menilai apakah kinerja yang dilakukan selama ini telah sesuai dengan tujuan yang ditetapkan sebelumnya melalui alat ukur keuangan dan pengendalian dalam perusahaan (organisasi).

\subsection{Penilaian Kesehatan}

Dengan lahirnya UU (Undang-Undang) Nomor 21 Tahun 2011 mengamanatkan peralihan kewenangan pengawasan terhadap lembaga penjaminan, yang awalnya diawasi oleh Menteri Keuangan kini dialihkan kepada Otoritas Jasa Keuangan (OJK) dan pengaturan mengenai lembaga penjaminan mengacu pada Peraturan Otoritas Jasa Keuangan (POJK). Sehubungan dengan amanat ketentuan pasal 42 ayat (4) Peraturan Otoritas Jasa Keuangan Nomor 2/POJK.05/2017 tentang Penyelenggaraan Usaha Lembaga Penjamin (Lembaran Negara Republik Indonesia Nomor 6014) perlu diatur ketentuan pelaksanaan mengenai tata cara pengukuran kesehatan keuangan bagi lembaga penjamin dalam Surat Edaran Otoritas Jasa Keuangan yang didalamnya mencakup penilaian atas Rasio Likuiditas, Gearing Ratio, Rentabilitas, dan Penilaian Sendiri (Self Assessment).

Tingkat kesehatan perusahaan dibutuhkan agar gambaran mengenai keuangan dalam perusahaan dapat terlihat apakah sedang dalam keadaan yang sehat atau tidak. Penilaian ini dapat dilakukan dengan membandingkan antara 2 elemen yang ada atau yang dinamakan dengan rasio.

\section{Metode Penelitian}

Jenis dan model penelitian ini penelitian deskriptif. Penelitian deskriptif adalah sebuah penelitian yang dilakukan untuk mengetahui variabel mandiri, baik satu variabel atau lebih (independen) tanpa membuat perbandingan atau menghubungkan dengan variabel yang lain (Sugiyono, 2011). Yaitu dengan mendeskripsikan kinerja keuangan PT Jaminan Pembiayaan Askrindo Syariah serta PT Penjaminan Jamkrindo Syariah.

Pendekatan yang digunakan dalam penelitian ini adalah sebuah studi kasus, yaitu pencarian hal-hal yang menyebabkan baik atau tidaknya kinerja keuangan PT Jaminan Pembiayaan Askrindo Syariah serta PT Penjaminan Jamkrindo Syariah. (Stake, 2006) memaparkan studi kasus sebagai metode penelitian yang memiliki tujuan penting dalam meneliti dan mengungkap keunikan serta kekhasan karakteristik yang terdapat dalam kasus yang diteliti, dimana kasus tersebut menjadi penyebab mengapa penelitian dilakukan. (Stake, 2006) menambahkan bahwa karena itulah dalam penelitian studi kasus perlu dilakukan penggalian informasi dan analisis mendalam mengenai segala hal yang berkaitan dengan kasus, baik sifat, kegiatan, sejarah, kondisi lingkungan dan fisik, fungsi, dan lain sebagainya.

Jenis data yang digunakan dalam penelitian ini adalah data sekunder. Data sekunder adalah data yang diperoleh dari data yang sudah ada dan dikumpulkan oleh pihak lain. Data ini 
biasanya bersumber dari penelitian lain yang telah dilakukan oleh institusi atau lembaga lain. Data sekunder yang diperoleh untuk penelitian ini adalah berupa laporan keuangan PT Jaminan Pembiayaan Askrindo Syariah dan PT Penjaminan Jamkrindo Syariah Tahun 2014-2018 dimana penilaian dasar tercantum pada peraturan yang ditetapkan oleh Otoritas Jasa Keuangan (OJK) dalam peraturan OJK (SAL SEOJK) Nomor 18/SEOJK.05/2018 yang ditetapkan di Jakarta pada 18 Desember 2018.

\section{Hasil dan Pembahasan}

\subsection{Rasio Likuiditas}

Rasio Likuiditas adalah rasio yang menggambarkan kemampuan Lembaga Penjamin dalam memenuhi kewajiban jangka pendek, yang dihitung dengan menggunakan current ratio, berupa perbandingan antara asset lancar dengan utang lancar. Likuiditas pada suatu perusahaan yang bernilai tinggi belum tentu baik bila ditinjau sari segi perusahaan tersebut. Menurut (Prastowo \& Julianty, 2005) Current Ratio yang tinggi dapat disebabkan oleh adanya piutang yang tidak tertagih atau persediaan yang tidak terjual yang tentu saja tidak dapat dipakai untuk membayar utang.

$$
\text { Rasio Likuiditas }=\frac{\text { Aset Lancar }}{\text { Utang Lancar }} \times 100 \%
$$

Tabel 4.1 Rasio Likuiditas PT Jaminan Pembiayaan Askrindo Syariah

\begin{tabular}{|c|c|c|c|c|}
\hline Tahun & Aset Lancar & Utang Lancar & Rasio & Skor \\
\hline 2014 & 119.596 .641 .238 & 15.083 .980 .889 & 792,872 & 1 \\
\hline 2015 & 319.613 .287 .967 & 41.994 .198 .481 & 761,089 & 1 \\
\hline 2016 & 348.493 .017 .999 & 53.032 .768 .838 & 657,128 & 1 \\
\hline 2017 & 376.601 .455 .709 & 80.718 .996 .276 & 466,559 & 1 \\
\hline 2018 & 384.347 .216 .654 & 75.696 .590 .961 & 507,747 & 1 \\
\hline
\end{tabular}

Sumber: Laporan keuangan Perusahaan yang diolah

Berdasarkan Salinan Surat Edaran Otoritas Jasa Keuangan (SAL SEOJK) Nomor 18/SEOJK.05/2018 tentang Kesehatan Keuangan Lembaga Penjamin rasio likuiditas PT Jaminan Pembiayaan Askrindo Syariah selama lima tahun periode yaitu sejak tahun 2014 - 2018 memperoleh bobot skor yang sama yaitu skor 1 dan menunjukkan performa yang baik karena mengartikan bahwa dalam menjalankan kegiatan usaha, perusahaan berada dalam keadaan yang baik dan dapat memenuhi kewajiban jangka pendeknya. Nilai rasio tertinggi terjadi di periode tahun 2014 dan 2015 yang menunjukkan nilai sebesar 792,872\% dan 761,089\%, sedangkan nilai rasio terendah terjadi pada tahun 2017 dengan nilai sebesar 466,559\%.

Tabel 4.2 Rasio Likuiditas PT Penjaminan Jamkrindo Syariah

\begin{tabular}{|c|c|c|c|c|}
\hline Tahun & Aset Lancar & Utang Lancar & Rasio & Skor \\
\hline 2014 & 248.690 .259 .969 & 433.637 .153 & 57349,851 & 5 \\
\hline 2015 & 285.518 .042 .034 & 31.533 .583 .064 & 905,441 & 5 \\
\hline 2016 & 336.185 .895 .366 & 93.889 .588 .369 & 358,065 & 1 \\
\hline 2017 & 426.594 .545 .792 & 195.472 .508 .229 & 218,238 & 1 \\
\hline
\end{tabular}




\begin{tabular}{|l|l|l|l|l|}
\hline 2018 & 646.086 .303 .110 & 406.145 .052 .263 & 159,078 & 1 \\
\hline
\end{tabular}

Sumber: Laporan keuangan Perusahaan yang diolah

Rasio Likuiditas yang terbentuk selama lima tahun periode milik PT Penjaminan Jamkrindo Syariah setelah di analisis menunjukkan hasil yang cukup baik karena membentuk skor 1 di tahun 2016, 2017 dan 2018. Dimana hal ini mengartikan bahwa kinerja perusahaan dalam memenuhi kewajiban jangka pendeknya memiliki performa yang sangat baik. Sedangkan untuk tahun 2014 dan tahun periode 2015 bobot skor yang dimiliki PT Penjaminan Jamkrindo Syariah membentuk skor 5, dimana menurut panduan SAL SEOJK No.18/SEOJK.05/2018 bobot skor 5 ini dianggap sebagai bobot yang kurang baik.

\subsection{Gearing Ratio}

Gearing Ratio adalah perbandingan antara total nilai penjaminan yang ditanggung sendiri dengan ekuitas Lembaga Penjamin pada waktu tertentu. Berdasarkan Salinan Surat Edaran Otoritas Jasa Keuangan (SAL SEOJK) Nomor 18/SEOJK.05/2018 tentang Kesehatan Keuangan Lembaga Penjamin.

$$
\text { Gearing Ratio }=\frac{\text { Total Penjaminan yang Ditanggung Sendiri }}{\text { Ekuitas Lembaga Penjamin }}
$$

Tabel 4.3 Gearing Ratio PT Jaminan Pembiayaan Askrindo Syariah

\begin{tabular}{|c|c|c|c|c|}
\hline Tahun & $\begin{array}{c}\text { Total Nilai Penjaminan } \\
\text { Yang Ditanggung Sendiri }\end{array}$ & $\begin{array}{c}\text { Ekuitas Lembaga } \\
\text { Penjamin Pada } \\
\text { Waktu Tertentu }\end{array}$ & Rasio & Skor \\
\hline 2014 & 47.407 .206 .739 & 110.689 .738 .325 & 0,428 & 5 \\
\hline 2015 & 111.148 .991 .593 & 284.742 .714 .797 & 0,390 & 5 \\
\hline 2016 & 156.215 .848 .198 & 304.176 .479 .066 & 0,514 & 5 \\
\hline 2017 & 176.300 .416 .260 & 310.635 .541 .615 & 0,568 & 5 \\
\hline 2018 & 223.484 .500 .864 & 325.531 .366 .747 & 0,687 & 5 \\
\hline
\end{tabular}

Sumber: Laporan keuangan Perusahaan yang diolah

Gearing Ratio yang didapatkan PT Jaminan Pembiayaan Askrindo Syariah periode tahun 2014 - 2018 menurut SAL SEOJK No.18/SEOJK.05/2018 termasuk kedalam kondisi yang buruk. Hal ini dikarenakan nilai rasio yang didapatkan berada pada skor 5 yang mengartikan bahwa kinerja perputaran perusahaan dalam mendapatkan kegiatan usaha utama dibandingkan dengan total ekuitas yang dimiliki perusahaan masih sangat kurang nilainya. Nilai rasio perusahaan di tahun 2014 menunjukkan nilai 0,428 dilanjutkan pada tahun 2015 sebesar 0,390 lalu pada tahun 2016 menunjukkan nilai sebesar 0,514 dan pada tahun 2017 serta 2018 menunjukkan nilai 0,568 dan 0,687 .

Analisa untuk fenomena gearing ratio yang terbentuk pada PT Jaminan Pembiayaan Askrindo Syariah periode tahun 2014 - 2018 menunjukkan bahwa bobot skor yang membentuk skor yang tidak baik ini disebabkan oleh kemampuan perusahaan dalam mendapatkan outstanding penjaminan kreditnya (dalam hal perusahaan syariah disebut imbal jasa kafalah) masih rendah. Agar bobot skor perusahaan dapat mendapatkan skor yang baik, yang dapat dilakukan perusahaan adalah dengan menambah jumlah penjaminan kredit yang dijaminkan dan meningkatkan tren yang ada seperti pada tahun 2014 - 2018 sehingga dapat merubah bobot skor perusahaan. 
Tabel 4.4 Gearing Ratio PT Penjaminan Jamkrindo Syariah

\begin{tabular}{|c|c|c|c|c|}
\hline Tahun & $\begin{array}{c}\text { Total Nilai } \\
\text { Penjaminan Yang } \\
\text { Ditanggung Sendiri }\end{array}$ & $\begin{array}{c}\text { Ekuitas Lembaga } \\
\text { Penjamin Pada } \\
\text { Waktu Tertentu }\end{array}$ & Rasio & Skor \\
\hline 2014 & 9.694 .330 & 250.252 .129 .625 & 0,000 & 5 \\
\hline 2015 & 18.893 .517 .921 & 256.991 .524 .257 & 0,074 & 5 \\
\hline 2016 & 44.558 .186 .225 & 260.869 .023 .269 & 0,171 & 5 \\
\hline 2017 & 68.832 .364 .309 & 469.331 .790 .157 & 0,147 & 5 \\
\hline 2018 & 151.895 .237 .797 & 746.638 .381 .732 & 0,203 & 5 \\
\hline
\end{tabular}

Sumber: Laporan keuangan Perusahaan yang diolah

Gearing ratio yang dimiliki oleh PT Penjaminan Jamkrindo Syariah dengan mengikuti panduan SAL SEOJK No.18/SEOJK.05/2018 selama lima tahun periode menunjukkan hasil yang kurang bagus. Hal ini terlihat dari hasil rasio selama tahun periode masih berada kurang dari 1 . Seperti pada tahun 2014 dan 2015 rasio yang ada menunjukkan nilai 0, lalu di tahun 2016 dan 2017 rasio mengalami sedikit perubahan menjadi 0,1 dan pada tahun 2018 rasio mengalami perubahan sehingga menghasilkan nilai 0,2. Dari keseluruhan nilai rasio tersebut skor yang terbentuk untuk gearing ratio ini PT Penjaminan Jamkrindo Syariah mendapatkan bobot skor 5, yang berarti kinerja perusahaan masih sangat kurang. Bobot yang menghasilkan skor 5 ini juga dapat diartikan bahwa kinerja perputaran perusahaan dalam mendapatkan kegiatan usaha utama dibandingkan dengan total ekuitas yang dimiliki perusahaan masih sangat kurang nilainya.

\subsection{Rentabilitas}

Rentabilitas adalah ukuran untuk mengetahui kemampuan Lembaga Penjamin dalam menghasilkan laba selama periode tertentu. Menurut (Hanafi \& Halim, 2009) Rasio Rentabilitas adalah rasio yang mengukur kemampuan perusahaan menghasilkan keuntungan pada tingkat penjualan, asset dan modal saham yang tertentu. Sedangkan menurut (Hery, 2015) pengukuran rasio ini bertujuan untuk memonitor dan mengevaluasi tingkat perkembangan profitabilitas perusahaan dari waktu ke waktu. Pada rasio Rentabilitas ini setidaknya terdapat tiga indikator yang diperlukan untuk menghitung nilai rasio, yang diantaranya adalah:

\subsubsection{Return On Asset}

Return on Asset (ROA) adalah rasio yang menunjukkan tingkat besarnya laba bersih sebelum pajak yang dihasilkan perusahaan pada akhir periode terhadap total asset yang dimiliki perusahaan di periode tersebut.

$$
\text { Return On Asset }=\frac{\text { Laba Sebelum Pajak }}{\text { Rata rata Total Asset }} \times 100 \%
$$

Tabel 4.5 ROA PT Jaminan Pembiayaan Askrindo Syariah

\begin{tabular}{|c|c|c|c|c|}
\hline Tahun & Laba Sebelum Pajak & Rata Rata Total Aset & Rasio & Skor \\
\hline 2014 & 12.624 .305 .804 & 125.773 .719 .214 & 10,037 & 1 \\
\hline 2015 & 31.423 .156 .443 & 326.736 .913 .278 & 9,617 & 1 \\
\hline 2016 & 25.262 .652 .756 & 357.209 .247 .905 & 7,072 & 1 \\
\hline
\end{tabular}




\begin{tabular}{|l|c|c|c|c|}
\hline 2017 & 6.783 .858 .801 & 391.354 .537 .891 & 1,733 & 3 \\
\hline 2018 & 22.729 .066 .672 & 401.227 .957 .708 & 5,665 & 1 \\
\hline
\end{tabular}

Sumber: Laporan keuangan Perusahaan yang diolah

PT Jaminan Pembiayaan Askrindo Syariah memperoleh nilai rasio ROA yang stabil selama empat tahun periode yaitu tahun 2014, 2015, 2016 dan 2018 karena mendapatkan bobot skor 1 walaupun trennya menunjukkan penurunan. Perubahan terjadi cukup signifikan pada tahun 2017 dikarenakan menurunnya nilai laba sebelum pajak dari periode sebelumnya dan mengakibatkan nilai rasio menunjukkan nilai 1,733\% sehingga berdampak pada bobot skor berubah yang berubah menjadi 3. Menurut SAL SEOJK No.18/SEOJK.05/2018 bobot skor 3 ini termasuk ke dalam kategori cukup baik karena nilai rasio berada pada rasio diantara $0 \%$ sampai dengan kurang dari $2,5 \%$. Sedangkan bobot skor dengan nilai 1 adalah rasio yang memiliki nilai sebesar 5\% atau lebih.

Tabel 4.6 ROA PT Penjaminan Jamkrindo Syariah

\begin{tabular}{|c|c|c|c|c|}
\hline Tahun & Laba Sebelum Pajak & Rata Rata Total Aset & Rasio & Skor \\
\hline 2014 & 1.214 .928 .157 & 250.685 .766 .778 & 0,485 & 3 \\
\hline 2015 & 10.269 .266 .044 & 288.525 .107 .321 & 3,559 & 2 \\
\hline 2016 & 10.862 .363 .590 & 354.758 .611 .638 & 3,062 & 2 \\
\hline 2017 & 15.902 .755 .126 & 469.331 .790 .157 & 3,388 & 2 \\
\hline 2018 & 24.887 .010 .000 & 746.638 .381 .732 & 3,333 & 2 \\
\hline
\end{tabular}

Sumber: Laporan keuangan Perusahaan yang diolah

Dari hasil perhitungan rasio ROA milik PT Penjaminan Jamkrindo Syariah menurut panduan SAL SEOJK No.18/SEOJK.05/2018 nilai rasio yang terbentuk menunjukkan hasil yang stabil untuk tahun 2015, 2016, 2017 dan 2018 karena menghasilkan bobot skor 2. Sedangkan di tahun awal periode yaitu tahun 2014 bobot skor yang terbentuk menunjukkan skor 3 karena nilai rasio menghasilkan nilai 0,485. Dari stabilnya bobot skor yang terbentuk dari rasio ini juga dapat disimpulkan bahwa kinerja perusahaan untuk indikator ROA ini telah tergolong kedalam kategori yang sudah baik.

\subsubsection{Rasio Operasional}

Rasio Operasional merupakan rasio yang digunakan untuk mengukur tingkat efisiensi dan kemampuan perusahaan dalam melaksanakan kegiatan operasional terhadap pendapatan operasional.

$$
\text { Rasio Operasional }=\frac{\text { Beban Operasional }}{\text { Pendapatan Operasional }} \times 100 \%
$$

Tabel 4.7 Rasio Operasional PT Jaminan Pembiayaan Askrindo Syariah

\begin{tabular}{|c|c|c|c|c|}
\hline Tahun & Beban Operasional & $\begin{array}{c}\text { Pendapatan } \\
\text { Operasional }\end{array}$ & Rasio & Skor \\
\hline 2014 & 15.094 .688 .729 & 43.006 .061 .642 & 35,099 & 1 \\
\hline 2015 & 42.802 .720 .024 & 96.200 .396 .724 & 44,493 & 1 \\
\hline 2016 & 82.455 .624 .920 & 143.221 .946 .524 & 57,572 & 1 \\
\hline 2017 & 80.599 .308 .644 & 122.289 .715 .338 & 65,908 & 1 \\
\hline 2018 & 75.098 .901 .038 & 156.030 .449 .949 & 48,131 & 1 \\
\hline
\end{tabular}

Sumber: Laporan keuangan Perusahaan yang diolah

Skor yang terbentuk untuk rasio operasional PT Jaminan Pembiayaan Askrindo 
Syariah selama periode tahun 2014 - 2018 menunjukkan skor yang stabil yaitu berbobot skor 1. Bila merujuk pada SAL SEOJK No.18/SEOJK.05/2018, bobot skor ini termasuk kedalam kategori sangat baik karena nilai rasio yang terbentuk menunjukkan nilai yang kurang dari 85\%. Walaupun demikian, nilai rasio yang dimiliki PT Jaminan Pembiayaan Askrindo Syariah selama periode tahun 2014 - 2018 juga mengalami peningkatan di empat tahun awal periode dan mengalami penurunan nilai rasio pada tahun 2018, yang bermula pada tahun 2017 bernilai 65,90\% turun menjadi 48,131\%.

Dari stabilnya skor yang terbentuk ini juga mengartikan bahwa kemampuan perusahaan dalam menjaga serta mengatur beban operasional perusahaan berada dalam kategori sangat baik. Hal yang perlu diperhatikan untuk periode yang akan datang adalah untuk tetap menjaga perbandingan beban operasional yang dimiliki terhadap pendapatan operasional yang didapatkan perusahaan. Walaupun jumlah beban operasional terus meningkat jumlahnya, hal ini dapat dijaga dengan cara meningkatkan pula pendapatan operasional perusahaan.

Tabel 4.8 Rasio Operasional PT Penjaminan Jamkrindo Syariah

\begin{tabular}{|c|c|c|c|c|}
\hline Tahun & $\begin{array}{c}\text { Beban } \\
\text { Operasional }\end{array}$ & $\begin{array}{c}\text { Pendapatan } \\
\text { Operasional }\end{array}$ & Rasio & Skor \\
\hline 2014 & 524.363 .474 & 9.694 .330 & 5408,971 & 5 \\
\hline 2015 & 7.444 .620 .843 & 20.124 .262 .516 & 36,993 & 1 \\
\hline 2016 & 11.618 .473 .822 & 48.076 .164 .586 & 24,167 & 1 \\
\hline 2017 & 15.017 .525 .399 & 73.908 .738 .231 & 20,319 & 1 \\
\hline 2018 & 24.503 .478 .060 & 160.862 .271 .701 & 15,233 & 1 \\
\hline \multicolumn{5}{|c|}{ Sumber: Laporan keuangan Perusahaan yang diolah } \\
\hline
\end{tabular}

Skor rasio operasional PT Penjaminan Jamkrindo Syariah menurut panduan SAL SEOJK No.18/SEOJK.05/2018 menunjukkan nilai yang stabil di tahun 2015, 2016, 2017 dan tahun 2018 dengan memperoleh bobot skor 1 yang mengartikan bahwa kinerja perusahaan dalam mengatur beban operasional perusahaan terhadap pendapatan operasional yang dimiliki perusahaan telah dikelola sangat baik. Sedangkan di awal tahun bobot skor yang terbentuk menunjukkan skor 5 yang mengartikan bahwa kinerja perusahaan dalam mengelola beban operasionalnya di tahun 2014 ini masih sangat rendah nilainya. Bila dilihat kembali, hal ini disebabkan oleh tingginya beban operasional di tahun ini sedangkan pendapatan operasional yang didapatkan masih kecil nilainya.

Dari hasil perhitungan yang ada, analisa yang dapat diberikan untuk perusahaan adalah untuk menjaga perbandingan rasio operasional di periode yang akan datang agar bobot skor kembali mendapatkan bobot skor 1 yang menunjukkan bahwa kinerja perusahaan berada di tingkat yang sangat baik. Walaupun misalnya tren beban operasional perusahaan menunjukkan tren yang meningkat di periode yang akan datang, namun jika pendapatan operasional perusahaan juga meningkat maka perbandingannya akan tetap menunjukkan skor yang baik.

\subsubsection{Rasio Klaim Imbal Jasa}

Rasio Klaim terhadap Pendapatan Imbal Jasa adalah rasio yang digunakan untuk megukur tingkat kinerja perusahaan penjaminan dengan menghitung dari perbandingan antara beban klaim neto terhadap Imbal Jasa neto.

$$
\text { Rasio Klaim Terhadap Imbal Jasa }=\frac{\text { Beban Klaim Neto }}{\text { Pendapatan IJK Neto }} \times 100 \%
$$


Tabel 4.9 Rasio Klaim Imbal Jasa PT Jaminan Pembiayaan Askrindo Syariah

\begin{tabular}{|c|c|c|c|c|}
\hline Tahun & $\begin{array}{c}\text { Beban Klaim } \\
\text { Neto }\end{array}$ & $\begin{array}{c}\text { Pendapatan Ijk } \\
\text { Neto }\end{array}$ & Rasio & Skor \\
\hline 2014 & 2.799 .122 .456 & 43.006 .061 .642 & 6,509 & 1 \\
\hline 2015 & 11.698 .323 .589 & 96.200 .396 .724 & 12,160 & 1 \\
\hline 2016 & 37.298 .363 .927 & 143.221 .946 .524 & 26,042 & 1 \\
\hline 2017 & 95.413 .964 .709 & 122.289 .715 .338 & 78,023 & 2 \\
\hline 2018 & 126.990 .102 .499 & 156.030 .449 .949 & 81,388 & 3 \\
\hline
\end{tabular}

Sumber: Laporan keuangan Perusahaan yang diolah

Bobot skor rasio klaim terhadap imbal jasa PT Jaminan Pembiayaan Askrindo Syariah periode tahun 2014 - 2018 terlihat mengalami perubahan di dua tahun terakhir periode. Padahal di tiga tahun awal periode yaitu tahun 2014, 2015 dan tahun 2016 bobot skor perusahaan mendapatkan skor yang sangat bagus yaitu skor 1 . Namun kemudian turun menjadi baik di tahun 2017 dengan bobot skor 2, dan akhirnya di tahun 2018 bobot skor berubah menjadi 3 yang mengartikan bahwa kinerja perusahaan menjadi cukup baik.

Dari hasil yang terbentuk untuk rasio klaim terhadap imbal jasa kafalah milik PT Jaminan Pembiayaan Askrindo Syariah mengalami penurunan kinerja di dua tahun akhir periode. Hal ini tidak terlepas disebabkan oleh meningkatnya secara signifikan beban klaim yang ditanggung perusahaan, sedangkan peningkatan pendapatan imbal jasa kafalah tidak terlalu mengalami perubahan yang signifikan. Akhirnya, perbandingan antara total beban klaim terhadap pendapatan imbal jasa kafalah menjadi berubah dan membuat bobot skor menjadi 2 dan 3.

Hal ini perlu diperhatikan perusahaan agar kembali meningkatkan kinerja perusahaan dengan cara meningkatkan jumlah penjaminan yang dijaminkan perusahaan agar pendapatan yang diterima perusahaan juga ikut meningkat. Sehingga, walaupun nilai total beban klaim yang ditanggung meningkat jumlahnya, rasio yang terbentuk masih dapat menghasilkan bobot skor yang tergolong baik karena nilai pendapatan imbal jasa kafalah masih tinggi jumlahnya.

Tabel 4.10 Rasio Klaim Imbal Jasa PT Penjaminan Jamkrindo Syariah

\begin{tabular}{|c|c|c|c|c|}
\hline Tahun & $\begin{array}{c}\text { Beban Klaim } \\
\text { Neto }\end{array}$ & $\begin{array}{c}\text { Pendapatan } \\
\text { Ijk Neto }\end{array}$ & Rasio & Skor \\
\hline 2014 & 2.090 .840 & 9.694 .330 & 21,568 & 1 \\
\hline 2015 & 583.975 .750 & 20.124 .262 .516 & 2,902 & 1 \\
\hline 2016 & 10.384 .926 .106 & 48.076 .164 .586 & 21,601 & 1 \\
\hline 2017 & 11.551 .320 .025 & 73.908 .738 .231 & 15,629 & 1 \\
\hline 2018 & 67.420 .379 .165 & 160.862 .271 .701 & 41,912 & 1 \\
\hline \multicolumn{5}{|c}{ Sumber: Laporan keuangan Perusahaan yang diolah } \\
\hline
\end{tabular}


Rasio klaim terhadap imbal jasa milik PT Penjaminan Jamkrindo Syariah selama lima tahun periode terlihat menunjukkan bobot skor yang stabil yaitu 1 dimana menurut panduan SAL SEOJK No.18/SEOJK.05/2018 bobot skor 1 termasuk kedalam skor dengan kinerja sangat baik. Dengan begitu, dapat disimpulkan bahwa selama lima tahun periode yang ada PT Penjaminan Jamkrindo Syariah menunjukkan kinerja yang sangat baik dalam mengatasi beban klaim perusahaannya terhadap pendapatan Imbal Jasa Kafalah yang didapatkan perusahaan. Bobot skor yang menunjukkan hasil sangat baik ini disebabkan oleh perbandingan antara beban klaim yang dimiliki perusahaan dapat ditutupi oleh besarnya pendapatan Imbal Jasa Kafalah yang didapatkan perusahaan. Sehingga menghasilkan nilai rasio yang menunjukkan bobot skor yang baik.

Dari hasil perhitungan untuk rasio klaim terhadap imbal jasa ini analisa yang dapat diberikan kepada perusahaan adalah untuk tetap menjaga kinerja serta performa perusahaan agar di periode yang akan datang bobot skor yang terbentuk akan kembali menghasilkan kinerja yang sangat baik. Walaupun tren beban klaim akan terus meningkat nilainya di periode mendatang, hal ini dapat diatasi dengan meningkatkan penjaminan yang dijaminkan perusahaan sehingga menghasilkan pendapatan imbal jasa kafalah yang lebih besar. Akibatnya rasio yang terjadi dapat menunjukkan hasil yang baik pula, karena perbandingan beban klaim dapat ditutupi oleh pendapatan imbal jasa kafalah yang didapatkan perusahaan.

\section{Penutup}

Hasil perhitungan dan analisis yang dilakukan terhadap penilaian kesehatan lembaga penjaminan syariah studi kasus PT Jaminan Pembiayaan Askrindo Syariah dan PT Penjaminan Jamkrindo Syariah menurut perhitungan dengan panduan SAL SEOJK No.18/SEOJK.05/2018 maka hasil yang diperoleh adalah tingkat kesehatan pada kedua perusahaan penjaminan ini termasuk kedalam kategori cukup sehat selama lima tahun periode. Namun pada tahun 2014 PT Penjaminan Jamkrindo Syariah mendapatkan tingkat kategori yang kurang sehat, hal ini dikarenakan bobot skor yang didapat pada setiap indikator keuangan di tahun tersebut mendapatkan bobot yang kurang baik sehingga berpengaruh pada penilaian tingkat kesehatan perusahaan itu sendiri.

Dari hasil itu pula maka masukan yang dapat diberikan kepada kedua perusahaan adalah untuk meningkatkan penilaian kesehatan, dapat dilakukan dengan meningkatkan kinerja keuangan perusahaan khususnya pada aspek gearing ratio. Karena baik PT Jaminan Pembiayaan Askrindo Syariah dan PT Penjaminan Jamkrindo Syariah pada indikator gearing ratio masih menunjukkan nilai rasio yang rendah selama lima tahun periode, padahal aspek ini merupakan salah satu aspek yang penting karena mencerminkan bagaimana perusahaan dalam mendapatkan banyaknya penjaminan yang didapatkan perusahaan. Sehingga untuk merubah nilai rasio dan skor yang ada, yang perlu dilakukan adalah dengan memperbanyak jumlah penjaminan yang dijaminkan sehingga dapat meningkatkan laba perusahaan sekaligus merubah tingkat kinerja dan nilai rasio yang terbentuk.

Pada PT Jaminan Pembiayaan Askrindo Syariah hasil yang didapatkan adalah perlu meningkatkan kinerja dua indikator keuangan yaitu ROA dan Rasio Klaim terhadap imbal jasa karena menunjukkan tren yang menurun di dua tahun periode terakhir, dan untuk PT Penjaminan Jamkrindo Syariah perlu meningkatkan kinerja pada indikator ROA karena bila dibandingkan dengan PT Jaminan Pembiayaan Askrindo Syariah dengan indikator yang sama, perusahaan ini telah mendapatkan tingkat yang sangat baik, sedangkan PT Penjaminan Jamkrindo Syariah masih berada di kondisi yang masih baik. 


\section{Daftar Pustaka}

Apriyanthi, R., Purbayati, R., \& Setiawan, S. (2020). Faktor-Faktor yang Mempengaruhi Pembiayaan Sektor Konstruksi pada Perbankan Syariah di Indonesia. ProBank: Jurnal Ekonomi Dan Perbankan. 5(1), 25-35.

Undang-Undang Republik Indonesia no 1 Tahun 2016 Tentang Penjaminan, Pub. L. No. 1, 1 (2016). www.bpkp.go.id

Fahmi, I. (2012). Analisis Kinerja Keuangan. Alfabeta.

FEUI, B. R. L. (2011). Analisis Bisnis Penjaminan Kredit: Sekilas Tinjanan Pasar International BUMN Jamkindo.

Halimatus, S., \& Mauluddi, H. A. (2018). Bank Muamalat Indonesia Profitability Analysis : Study Of The Effects Of Capital, Asset Quality, Earnings And Liquidity Analisis Profitabilitas Bank Muamalat Indonesia: Studi Pengarub Permodalan, Kualitas Asset, Earnings Dan. 14(1), 69-81.

Hanafi, M., \& Halim, A. (2009). Analisis Laporan Kenangan. UPP STIM YKPN.

Hery. (2015). Analisis Laporan Kenangan. CAPS (Central of Academic Publishing Service).

Mardiasmo. (2010). Abstraksi Peraturan Pemerintah No 60 Tabun 2008 SPIP dan Peran SPIP dalam Reformasi Birokrasi. Perwakilan BPKP Prov Sulawesi Selatan.

SAL SEOJK No.18/SEOJK.05/2018, 1 (2018). www.ojk.go.id

Prastowo, D., \& Julianty, R. (2005). Analisis Laporan Keuangan Konsep dan Aplikasi. UPP AMP YKPN.

Setiawan, I. (2020). Analisis Peran Perbankan Terbadap Pertumbuban Ekonomi di Indonesia : Bank Syariah Versus Bank Konvensional. 8(1), 52-60.

Setiawan, R. W. (2017). Analisis Rasio Keuangan Untuk. Menilai Kienerja BUMN Penugasan Khusus Penjaminan Kredit Usaha Rakyat Pada PT Asuransi Kredit Indonesia (Persero) Dan Perusahaan Umum Jaminan Kredit Indonesia Tabun 2014-2016. Universitas Terbuka.

Setiawan, S., Wulansari, P., \& Dewi, R. P. K. (2020). Pengukuran Tingkat Kinerja Keuangan Dan Kinerja Non Keuangan Pada Bank Syariah Di Lima Negara Asia (Studi Kasus Pada Bank Syariah Dengan Aset Tertinggi). Dinamika Akuntansi Kenangan dan Perbankan, 9(1), 69-78.

Stake, R. . (2006). Multiple Case Study Analysis. Guilford Press.

Sugiyono. (2011). Metode Penelitian Kuantitatif Kualitatif dan R\&D Cetakan ke-14. Alfabeta. 